\title{
Underutilization of the Clinical Microbiology Laboratory by Physicians in Nigeria
}

\author{
${ }^{1}$ Iregbu, K. C., ${ }^{2}$ Osuagwu, C. S., ${ }^{3}$ Umeokonkwo, C. D., ${ }^{4}$ Fowotade, A. A., ${ }^{5}$ Ola-Bello, O. I., \\ ${ }^{1}$ Nwajiobi-Princewill, P. I., ${ }^{6}$ Taiwo S. S., ${ }^{7}$ Olayinka A. T., and $*^{2}$ Oduyebo, O. 0. \\ ${ }^{1}$ Department of Medical Microbiology, National Hospital, Abuja \\ ${ }^{2}$ Department of Medical Microbiology and Parasitology, College of Medicine, University of Lagos \\ ${ }^{3}$ Department of Community Medicine, Alex Ekwueme Federal University Teaching Hospital, Abakaliki, Ebonyi State \\ ${ }^{4}$ Department of Medical Microbiology and Parasitology, University College Hospital, Ibadan \\ ${ }^{5}$ Department of Medical Microbiology, State Specialist Hospital, Akure \\ ${ }^{6}$ Department of Medical Microbiology and Parasitology, College of Health Sciences, \\ Ladoke Akintola University of Technology, Ogbomoso \\ ${ }^{7}$ Department of Medical Microbiology, College of Health Sciences, Ahmadu Bello University, Zaria \\ *Correspondence to: oyinoduyebo@yahoo.com; +2348023163319; ORCiD: 0000-0002-2894-4367
}

\section{Abstract:}

Background: Clinical laboratories are critical to correct diagnosis of medical conditions to ensure appropriate management. Point prevalence survey (PPS) of antimicrobial use and resistance performed in Nigeria in 2015 and 2017 showed high rates of antibiotic use, but poor laboratory utilization for definitive diagnosis of the infections for which the antimicrobials were prescribed. This study investigated the reasons for clinicians' poor utilization of the clinical laboratory for definitive diagnosis and treatment of infections.

Methods: A cross sectional survey of clinicians attending the 2018 annual scientific conference and general meeting of the National Postgraduate Medical College of Nigeria (NPMCN) in Owerri, Southeastern Nigeria, was conducted using self-administered structured questionnaire to obtain information on the sub-optimal utilization of the clinical microbiology laboratory.

Results: Of 283 respondents, $14.8 \%$ were general practitioners and $85.2 \%$ were specialists who have been in practice for a median period of 20 years (range 3 - 48 years). The specialists included surgeons (26\%), family physicians $(19.8 \%)$, internists $(14.3 \%)$, pathologists $(13.9 \%)$, paediatricians $(8.8 \%)$, obstetricians and gynecologists $(8.1 \%)$, community medicine physicians $(6.2 \%)$, and dental surgeons (2.6\%). Majority of the respondents $(90.8 \%)$ work in public, $88.3 \%$ work in tertiary and $9.9 \%$ in secondary care hospitals. For diagnosis of infections, $16 \%$ and $49.8 \%$ reported using laboratory "always" and "very often" respectively. Among these, the most commonly utilized investigations were microscopy, culture and sensitivity (62.4\%), DNA detection (18.3\%), GeneXpert for tuberculosis (17.2\%), and antigen detection (16.7\%). Among clinicians that "hardly make use" of the laboratory, their reasons for non-use were; clinical diagnosis being sufficient $(39.7 \%)$, delayed results (17.2\%), having knowledge of 'potent' antibiotics (15.5\%), lack of access to microbiology laboratory (13.8\%), absence of pathologists to assure quality of tests $(12.1 \%)$, and no need of the laboratory to manage patients with infections $(8.6 \%)$.

Conclusion: These findings indicate that poor use of the microbiology laboratory seems mainly associated with perception and attitude of the physicians to the relevance of the laboratory, and perceived inadequacy of microbiology practice in some others. There is need to raise physicians' awareness on the relevance and what constitutes optimal use of the clinical microbiology laboratory for accurate diagnosis of infections and appropriate antimicrobial use.

Key words: utilization, microbiology laboratory, diagnosis, antimicrobials, infectious diseases

Received October 17, 2019; Revised October 24, 2019; Accepted October 25, 2019

Copyright 2020 AJCEM Open Access. This article is licensed and distributed under the terms of the Creative Commons Attrition 4.0 International License (http://creativecommmons.org/licenses/by/4.0), which permits unrestricted use, distribution and reproduction in any medium, provided credit is given to the original author(s) and the source. 


\title{
Sous-utilisation du laboratoire de microbiologie clinique par des médecins au Nigéria
}

\author{
${ }^{1}$ Iregbu, K. C., ${ }^{2}$ Osuagwu, C. S., ${ }^{3}$ Umeokonkwo, C. D., ${ }^{4}$ Fowotade, A. A., ${ }^{5}$ Ola-Bello, O. I., \\ ${ }^{1}$ Nwajiobi-Princewill, P. I., ${ }^{6}$ Taiwo S. S., ${ }^{7}$ Olayinka A. T., et $*^{2}$ Oduyebo, O. O. \\ ${ }^{1}$ Département de microbiologie médicale, hôpital national, Abuja \\ ${ }^{2}$ Département de microbiologie médicale et de parasitologie, faculté de médecine, université de Lagos \\ ${ }^{3}$ Département de médecine communautaire, Alex Ekwueme Hôpital universitaire fédéral, Abakaliki, Etat d'Ebonyi \\ ${ }^{4}$ Département de médecine microbiologique et de parasitologie, Université universitaire Ibadan \\ ${ }^{5}$ Département de microbiologie médicale, Hôpital d'État spécialisé, Akure \\ ${ }^{6}$ Département de microbiologie médicale et de parasitologie, Collège des sciences de la santé, Université \\ de technologie Ladoke Akintola, Ogbomoso \\ ${ }^{7}$ Département de Microbiologie médicale et du Collège des sciences de la santé, Université Ahmadu Bello, Zaria \\ *Correspondance à: oyinoduyebo@yahoo.com; +2348023163319; ORCiD: 0000-0002-2894-4367
}

\begin{abstract}
Abstrait:
Contexte: Les laboratoires cliniques sont essentiels pour corriger le diagnostic des conditions médicales et assurer une prise en charge appropriée. Une enquête de prévalence ponctuelle (PPS) sur l'utilisation et la résistance aux antimicrobiens réalisée au Nigéria en 2015 et 2017 a montré des taux élevés d'utilisation d'antibiotiques, mais une faible utilisation en laboratoire pour le diagnostic définitif des infections pour lesquelles les antimicrobiens ont été prescrits. Cette étude a examiné les raisons de la faible utilisation du laboratoire par les cliniciens pour le diagnostic définitif et le traitement des infections.

Méthodes: Une enquête transversale sur les cliniciens participant à la conférence scientifique annuelle et à l'assemblée générale de 2018 du Collège national des médecins diplômés du Nigéria (NPMCN) à Owerri, dans le sud-est du Nigéria, a été réalisée à l'aide d'un questionnaire structuré auto-administré visant à obtenir des informations sur le sous-optimal. utilisation du laboratoire de microbiologie clinique.

Résultats: Sur 283 répondants, $14,8 \%$ étaient des omnipraticiens et $85,2 \%$ des spécialistes exerçant depuis 20 ans en moyenne (de 3 à 48 ans). Les spécialistes comprenaient des chirurgiens (26\%), des médecins de famille $(19,8 \%)$, des internistes $(14,3 \%)$, des pathologistes $(13,9 \%)$, des pédiatres $(8,8 \%)$, des obstétriciens et des gynécologues $(8,1 \%)$, des médecins de santé communautaires $(6,2 \%)$, et chirurgiens dentistes $(2,6 \%)$. La majorité des répondants $(90,8 \%)$ travaillent en public, $88,3 \%$ dans le tertiaire et $9,9 \%$ dans les hôpitaux de soins secondaires. Pour le diagnostic des infections, $16 \%$ et $49,8 \%$ ont déclaré utiliser le laboratoire «toujours» et «très souvent» respectivement. Parmi ceux-ci, les examens les plus couramment utilisés étaient la microscopie, la culture et la sensibilité $(62,4 \%)$, la détection de I'ADN $(18,3 \%)$, GeneXpert pour la tuberculose (17,2\%) et la détection de l'antigène $(16,7 \%)$. Parmi les cliniciens qui «utilisent à peine» le laboratoire, les raisons de leur nonutilisation étaient: diagnostic clinique suffisant $(39,7 \%)$, résultats tardifs $(17,2 \%)$, connaissance d'antibiotiques «puissants» $(15,5 \%)$, manque d'accès au laboratoire de microbiologie $(13,8 \%)$, absence de pathologistes pour garantir la qualité des tests $(12,1 \%)$, et aucun laboratoire n'a besoin de prendre en charge des patients infectés $(8,6 \%)$.

Conclusion: Ces résultats indiquent que la mauvaise utilisation du laboratoire de microbiologie semble principalement associée à la perception et à l'attitude des médecins à l'égard de la pertinence du laboratoire, et à l'insuffisance perçue de la pratique de la microbiologie chez certains autres. Il est nécessaire de sensibiliser les médecins à la pertinence et à l'utilisation optimale du laboratoire de microbiologie clinique pour un diagnostic précis des infections et une utilisation appropriée des antimicrobiens.
\end{abstract}

Mots-clés: utilisation, laboratoire de microbiologie, diagnostic, antimicrobiens, maladies infectieuses

\section{Introduction:}

Antimicrobial resistance is increasing globally and locally $(1,2,3)$. Multidrug resistant organisms have been isolated from clinical and environmental sources in different parts of Nigeria and their rates are on the increase $(3,4,5)$. Rational antibiotic use is needed to reduce selection pressure on bacteria and curb development of antibiotic resistance. This involves use of antibiotic policy and guidelines for antibiotic prescriptions. To produce a meaningful antibiotics guideline, locally gene- rated data on the antibiogram of the prevailing pathogenic bacteria in an area are recommended (6). Targeted antimicrobial therapy, as recommended by antimicrobial stewardship, is one of the ways to achieve rational antibiotic use (7). This involves the identification and determination of antimicrobial susceptibility pattern of the offending pathogens.

Antibiotic guideline and targeted antimicrobial therapy require the utilization of the clinical microbiology laboratory. To optimize accurate diagnosis of infectious diseases, clinicians need to ensure that diagnostic 
specimens are properly collected, transported and promptly submitted to the clinical microbiology laboratory, preferably before the initiation of antimicrobial therapy (8). Even in life-threatening conditions such as sepsis and septic shock where prompt initial antibiotic therapy is associated with better outcome, it is still recommended that blood culture samples be obtained before initiation of antibiotic treatment, though without delaying the latter. Many infectious conditions hardly require instant antimicrobial administration, therefore, the time spent for proper diagnosis and prudent selection of antibiotics will be of great benefit to the patient and the health care system in the long run. Biomarkers such as procalcitonin and C-reactive protein levels are usually employed to guide empiric antibiotic therapy, which is usually broad spectrum or involves combination therapy. Treatment may need to be de-escalated and the antibiotic spectrum narrowed as soon as culture and susceptibility pattern are ascertained. This reduces the incidence of adverse events and cost, as well as delay the emergence of antimicrobial resistance.

Point prevalence survey (PPS) of antimicrobial prescription and resistance conducted in Nigeria in 2015 and 2017 showed very high rates of antibiotic use and poor laboratory utilization for definitive diagnosis of infections for which the antimicrobials were prescribed $(9,10)$. These findings raised the question as to why clinicians are not optimally utilizing the clinical microbiology laboratory. The objective of this study was therefore to determine the reasons for clinicians' suboptimal utilization of the clinical microbiology laboratory in Nigeria for diagnosis of infections.

\section{Materials and method:}

\section{Study setting}

The study setting is Nigeria which operates a three-tiered hierarchical health structure; primary, secondary and tertiary health facilities (11). Each tier is manned by certain categories of health manpower that render specified range of services to the public. Irrespective of the tier, the health facility could be publicly or privately funded. The secondary and tertiary health facilities are more likely to have full laboratory support compared to the primary health facilities. Health facilities without laboratory support often depend on the privately-owned laboratory facilities. Most of the specialists practice in the secondary and tertiary health facilities.
Study design, population and sample size

We conducted a descriptive crosssectional survey of specialists attending the annual scientific conference and general meeting of the National Postgraduate Medical College of Nigeria (NPMCN) in Owerri, Southeastern Nigeria, in August 2018. The NPMCN has trained over 7,000 specialists, with about 4,000 currently practicing in Nigeria. The conference was attended by 800 delegates (personal communication).

The sample size was calculated using the formula for estimating single independent proportion (12). We assumed $50 \%$ utilization of laboratory services and $5 \%$ level of significance. We also adjusted for a population less than 10,000 and $75 \%$ response rate. This gave us the sample size of 468 , which was approximated to 470 .

\section{Sampling technique and data collection}

We used a semi-structured pre-tested questionnaire to collect information on sociodemographic characteristics, use of clinical microbiology laboratory for diagnosis of infections, and reasons for non-use of the laboratory, from each participant. The participants from different specialties were selected by ballot without replacement method of simple random sampling technique, and the questionnaires were hand-delivered to and self-administered by each participant.

The degree of utilization of the clinical microbiology laboratory services was ranked as 'always', 'very often', 'occasionally', 'not often', 'rarely' and 'never'. Responses of 'always' and 'very often' were categorized as 'good use' while others were categorized as 'poor use' of the laboratory.

\section{Data analysis}

Data were analyzed using EPI INFO version 7.2 (US CDC). The socio-demographic characteristics and the degree of use of clinical microbiology laboratory were presented as frequency and proportions. The relationship between use of clinical microbiology laboratory and socio-demographic characteristics were examined using Chi square test at $5 \%$ level of significance. The odd ratio and $95 \%$ confidence interval of the odds were estimated.

\section{Results:}

Only 283 participants returned completed questionnaires giving a response rate of $60.2 \%$. There were $207(73.1 \%)$ males, with male: female ratio of $2.7: 1$. The age group $45-$ 
49years constituted the largest group (25.2\%). Forty-two (14.8\%) respondents were general practitioners while $241(85.2 \%)$ were specialists who have been in practice for a median period of 20 years (3-48years). The specialists included general surgeons $(26 \%)$, family physicians $(19.8 \%)$, internists $(14.3 \%)$, pathologists $(13.9 \%)$, paediatricians $(8.8 \%)$, obstetricians and gynecologists (8.1\%), community medicine physicians (6.2\%), and dental surgeons $(2.6 \%)$ (Table 1 ). Majority of the respondents $(90.8 \%, \mathrm{n}=257)$ work in public hospitals, 250 (88.3\%) work in tertiary and 28 $(9.9 \%)$ in secondary care hospitals

One hundred and eighty six (65.7\%) of the respondents made good use of the laboratory; 45 (15.9\%) always and 141 $(49.8 \%)$ very often, while 97 (34.3\%) made use of the laboratory poorly; 35 (12.4\%) use the facility occasionally, 39 (13.8\%) not often,
$18(6.3 \%)$ rarely, and $5(1.8 \%)$ never (Table $2)$. The reasons for utilization were microscopy, culture and sensitivity (62.4\%), nucleic acid detection (18.3\%), GeneXpert (17.2\%) and antigen detection (16.7\%) (Table $2)$. Nucleic acid detection was used mainly for follow up for hepatitis B management.

Reliance on clinical diagnosis (39.7\%) and perceived patient's inability to afford the cost of the laboratory test were the most common reasons given by the respondents for non-use of the laboratory. Others were the prolonged turnaround time, lack of access to medical microbiology laboratory, and having knowledge of potent antibiotics (Table 2). None of the factors examined was significantly associated with good use of the clinical microbiology laboratory for diagnostic purposes (Table 3).

Table 1: Socio-demographic characteristics of respondents

\begin{tabular}{|c|c|c|}
\hline Variable & Frequency & Percentage (\%) \\
\hline \multicolumn{3}{|l|}{ Gender } \\
\hline Male & 207 & 73.1 \\
\hline Female & 76 & 26.9 \\
\hline \multicolumn{3}{|l|}{ Age group (years)* } \\
\hline $35-39$ & 17 & 6.0 \\
\hline $40-44$ & 51 & 18.1 \\
\hline $45-49$ & 71 & 25.2 \\
\hline $50-54$ & 54 & 19.2 \\
\hline $55-59$ & 42 & 14.9 \\
\hline $60-64$ & 28 & 9.9 \\
\hline$\geq 65$ & 19 & 6.7 \\
\hline \multicolumn{3}{|l|}{$\begin{array}{l}\text { Mean age } \pm \text { SD } \\
\text { Branch of Medicine }\end{array}$} \\
\hline Physician & 177 & 62.5 \\
\hline Surgeon & 106 & 37.5 \\
\hline \multicolumn{3}{|l|}{ General Practitioner } \\
\hline Yes & 42 & 14.9 \\
\hline No & 241 & 85.1 \\
\hline \multicolumn{3}{|l|}{ Specialty* } \\
\hline General Surgeon & 72 & 26.4 \\
\hline Family Physician & 54 & 19.8 \\
\hline Internist & 39 & 14.3 \\
\hline Pathologist & 38 & 13.9 \\
\hline Paediatrician & 24 & 8.8 \\
\hline Obstetrics \& Gynaecologist & 22 & 8.1 \\
\hline Community Physician & 17 & 6.2 \\
\hline Dental Surgeon & 7 & 2.6 \\
\hline \multicolumn{3}{|l|}{ Place of Practice } \\
\hline Public & 257 & 90.8 \\
\hline Private & 15 & 5.3 \\
\hline Faith based & 11 & 3.9 \\
\hline \multicolumn{3}{|l|}{ Level of practice } \\
\hline Tertiary & 250 & 88.3 \\
\hline Secondary & 28 & 9.9 \\
\hline \multirow{2}{*}{\multicolumn{3}{|c|}{ Duration of practice (years) }} \\
\hline & & \\
\hline $1-10$ & 29 & 10.3 \\
\hline $11-20$ & 122 & 43.1 \\
\hline $21-30$ & 64 & 22.6 \\
\hline$>30$ & 68 & 24.0 \\
\hline
\end{tabular}


Table 2: Patterns of utilization of clinical microbiology laboratory by clinicians for patient management

\begin{tabular}{|c|c|c|}
\hline Variable & Frequency & Percentage (\%) \\
\hline \multicolumn{3}{|l|}{ Use of microbiology laboratory for diagnosis of infections $(n=283)$} \\
\hline Always & 45 & 15.9 \\
\hline Very often & 141 & 49.8 \\
\hline Occasionally & 35 & 12.4 \\
\hline Not often & 39 & 13.8 \\
\hline Rarely & 18 & 6.3 \\
\hline Never & 5 & 1.8 \\
\hline \multicolumn{3}{|l|}{ Laboratory investigations often requested for $(n=186) *$} \\
\hline Bacteria culture and susceptibility tests & 116 & 62.4 \\
\hline Nucleic acid detection & 34 & 18.3 \\
\hline GeneXpert & 32 & 17.2 \\
\hline Antigen detection & 31 & 16.7 \\
\hline Microscopy & 4 & 2.2 \\
\hline Others & 59 & 31.7 \\
\hline \multicolumn{3}{|l|}{ Nucleic acid detection $(n=34)$} \\
\hline Hepatitis B & 7 & 20.6 \\
\hline Paternity dispute & 2 & 5.9 \\
\hline TB MDR & 2 & 5.9 \\
\hline Sex determination & 1 & 2.9 \\
\hline Hepatitis C & 1 & 2.9 \\
\hline \multicolumn{3}{|l|}{ Reasons for non-use of laboratory for diagnosis of infections $(n=58) *$} \\
\hline Clinical diagnosis is sufficient & 23 & 39.7 \\
\hline Patients cannot afford the cost & 12 & 20.7 \\
\hline Results are always delayed so irrelevant to patient management & 10 & 17.2 \\
\hline Already know potent antibiotics and no need for test & 9 & 15.5 \\
\hline No access to medical microbiology laboratory & 8 & 13.8 \\
\hline No pathologist to ensure quality of test & 7 & 12.1 \\
\hline I don't need lab to manage patients with infections & 5 & 8.6 \\
\hline Others & 19 & 32.8 \\
\hline
\end{tabular}

*Multiple responses allowed

Table 3: Factors associated with laboratory utilization by clinicians

\begin{tabular}{lccc}
\hline \multicolumn{1}{c}{ Variable } & \multicolumn{2}{c}{ Laboratory utilization } & Crude Odds ratio \\
Good (\%) & Poor (\%) & (95) \\
\hline Gender & $137(66.2)$ & $70(33.8)$ & $1.1(0.62-1.87)$ \\
Male & $49(64.5)$ & $27(35.5)$ & 1 \\
$\begin{array}{c}\text { Female } \\
\text { General Practitioner }\end{array}$ & $28(66.7)$ & $14(33.3)$ & $1.1(0.53-2.11)$ \\
Yes & $157(65.4)$ & $83(34.6)$ & 1 \\
No & & & $1.0(0.63-1.93)$ \\
Branch of Medicine & $117(66.1)$ & $60(33.9)$ & 1 \\
$\quad \begin{array}{l}\text { Physicians } \\
\text { Surgeons }\end{array}$ & $69(65.1)$ & $37(34.9)$ & \\
Level of Practice & & & $1.0(0.44-2.05)$ \\
Tertiary & $164(65.6)$ & $86(34.4)$ & 1 \\
$\quad$ Others & $22(66.7)$ & $11(33.3)$ & \\
Duration of Practice (years) & & & $0.6(0.26-1.56)$ \\
$1-10$ & $16(55.2)$ & $13(44.8)$ & $0.9(0.49-1.69)$ \\
$11-20$ & $77(63.1)$ & $45(36.9)$ & $1.6(0.73-3.35)$ \\
$21-30$ & $48(75.0)$ & $16(25.0)$ & 1 \\
$>30$ & $45(66.2)$ & $23(33.8)$ & \\
\hline
\end{tabular}

\section{Discussion:}

This study revealed suboptimal use of the clinical microbiology laboratory, contrary to the practice in western countries where studies have shown that there is over utilization of the clinical laboratories and efforts are actually being made to reduce this $(13,14,15)$. The clinical microbiology laboratory plays a vital role in the management of infectious diseases. Non utilization of the laboratory has dire consequences as diagnosis of infectious diseases based on symptoms and signs lead to both over and under-diagnosis or outright 
misdiagnosis of some infections. These have clinical implications including over and inappropriate prescription of antibiotics, wastages, infection complications, economic consequences, and potential fatal outcome $(10,16,17,18)$.

One of the reasons for non-use of the clinical laboratory by physicians in this survey is the presumed sufficiency of clinical diagnosis, thereby making microbiology investigations unnecessary. Similar findings have been reported in other African countries where doctors express doubt about accuracy of laboratory results or are confused by them and therefore prefer to follow up patients rather than use the laboratory $(19,20,21,22)$. In these countries, poor laboratory infrastructure or personnel have been blamed for this, but in our study, respondents who work in reputable tertiary hospitals with good clinical microbiology laboratories and qualified pathologists did not make effective use of the laboratories $(19,20,21,22)$.

Some of the respondents claim to already have knowledge of potent antibiotics and therefore do not require the laboratory. This view may be the result of lack of knowledge of the critical role clinical microbiology laboratory plays in the diagnosis and treatment of infectious diseases, as well as low awareness and/or absence of antimicrobial stewardship programmes in most Nigerian hospitals at the time of the survey. This may be responsible for high use of antibiotics noted in some surveys $(9,10,23,24)$. The obvious lack of association between poor clinical microbiology utilization and any of the sociodemographic variables analysed highly suggests that poor clinical microbiology laboratory utilization is a habit or behavioural anomaly that cuts across the spectrum of doctors.

The low utilization of nucleic acid detection tests suggests possibility of poor diagnosis of viral infections. This is a cause for concern as a significant proportion of viral infections are often mistreated with antibiotics thus paving way for subsequent development of antimicrobial resistance. Previous studies have reported over prescribing of antibiotics for viral diseases (25).

One limitation of the study was the use of subjective adjectives in describing the degree of laboratory utilization. The study participants were specialists whom we believed have good understanding of the words and were honest in their responses. However, in view of the very low rate targeted antibiotic therapy obtained in previously performed surveys, the rate of non-use of the microbiology laboratory confessed may well be an underestimate and need to be corroborated with other studies $(9,10)$. Another limitation may be the high level of non response rate that is typical of such settings.

\section{Conclusion:}

The results of this study confirm that physicians' use of the clinical microbiology laboratory in Nigeria for diagnosis of infection is suboptimal and needs to be improved on. The reasons for these are mainly physicians' perception that clinical diagnosis is sufficient, delayed laboratory results, poor access to microbiology laboratory, and lack of qualified pathologists. There is urgent need for education of physicians to optimally utilize the microbiology laboratory to improve their antibiotics prescribing practice, and also the need to raise awareness among them on what constitutes optimal use of the laboratory for diagnosis and appropriate management of infections.

\section{References:}

1. Prestinaci, F., Pezzotti, P., and Pantosti, A. Antimicrobial resistance: a global multifaceted phenomenon. Pathog Glob Health. 2015; 109 (7): 309318.

2. Bernabé, K. J., Langendorf, C.. Ford, N., JeanBaptiste., R. J., and Murphy, A. R. Antimicrobial resistance in West Africa: a systematic review and meta-analysis. Int J Antimicrob Agents. 2017; 50 (5): 629-639

3. Oduyebo, O. O., Onwuezobe, I. A., Olayemi, S. O. and Akintunde, A. S. Correlating Antibiotic Consumption With Antimicrobial Resistance of Uropathogens In a University Teaching Hospital In Lagos, Nigeria. Nig J Clin Pract. 2008; 11(4): 305308

4. Shittu, A. O., Okon, K., Adesida, S., Oyedara, O., Witte, W., Strommenger, B., Layer, F., and Nübel, $\mathrm{U}$. Antibiotic resistance and molecular epidemiology of Staphylococcus aureus in Nigeria. BMC Microbiol. 2011; 11: 92

5. Nmema, E. E. Peculiar pattern of antibiotic resistance in bacteria isolated from various sources in South-East Nigeria and the implications in health and economy. J Appl Sci Environ Manag. 2013; 17 (4): 529-534

6. World Health Organization SEARO: Step-by-step approach for development and implementation of hospital antibiotic policy and standard treatment guidelines, 2011

7. CDC. Core Elements of Hospital Antibiotic Stewardship Programs, Available from https://www.cdc.gov/antibiotic-use/coreelements/hospital.html

8. Leekha, S., Terrell, C. L., and Edson, R. S. General Principles of Antimicrobial Therapy. In Mayo Clin Proc. $2011 ; 86$ (2): 156-167.

9. Oduyebo, O, O., Iregbu, K. C., Chukwuma, U., et al. The Global Point Prevalence Survey of Antimicrobial Consumption and Resistance (Global-PPS): Results of Antimicrobial Prescribing 
in Nigerian Hospitals. In proceedings of $28^{\text {th }}$ ECCMID conference; 2018 April 21-24, Madrid, Spain. ESCMID abstract publications; 2018. E0034

10. Oduyebo, O. O., Olayinka, A. T., Iregbu, K.C., et al. A point prevalence survey of antimicrobial prescribing in four Nigerian Tertiary Hospitals. Ann Trop Pathol. 2017; 8: 42-46

11. National Health Act 2014. Federal Republic of Nigeria, Official Gazette No. 145 (101) Notice No. 208

12. Cochran, W. G. Sampling Techniques, $3^{\text {rd }}$ Ed., New York: John Wiley and Sons, Inc., 1977.

13. Minerowicz, C., Abel N., Hunter K., Behling, K. C. Cerceo, E., and Bierl, C. Impact of weekly feedback on test ordering patterns. Am J Manag Care. 2015; 21: 763-768

14. Kobewka, D. M., Ronksley, P. E., McKay, J. A. Forster, A. J., and Van Walraven, C. Influence of educational, audit and feedback, system based, and incentive and penalty interventions to reduce laboratory test utilization: A systematic review. Clin Chem Lab Med. 2015; 53: 157-183.

15. Zhi M., Ding, E. L., Theisen-Toupal J., Whelan, J., and Arnaout, R. The landscape of inappropriate laboratory testing: a 15-year meta-analysis. PLoS One. 2013; 8: e78962.

16. Bindraban, R. S., ten Berg, M. J., Naaktgeboren, C. A., Kramer, M. H., van Solinge, W. W., and Nanayakkara, P. W. Reducing Test Utilization in Hospital Settings: A Narrative Review. Ann Lab Med. 2018; 38 (5): 402-412.

17. Ngwu, B. A., and Agbo, J. A. Typhoid fever: clinical diagnosis versus laboratory confirmation. Niger J Med. 2003; 12: 187-192
18. Petti, C. A., Polage C. R., Quinn, T. C., Ronald, A. R., and Sande, M. A. Laboratory Medicine in Africa: A Barrier to Effective Health Care. Clin Infectious Dis. 2006; 42 (3): 377-382. https://doi.org/10.1086/499363

19. Oladosu, O. O. and Oyibo, W. A. Over diagnosis and Overtreatment of Malaria in Children That Presented with Fever in Lagos, Nigeria. ISRN Infect Dis. 2013; 2013: 6. http://dx.doi.org/10.5402/2013/914675

20. Vanker, N., and Faull, N. H. Laboratory test result interpretation for primary care doctors in South Africa. Afr J Lab Med. 2017; 6 (1): 1-6 https://doi.org/10.4102/ajlm.v6i1.453

21. Moyo, K., Porter, C., Chilima, B., et al. Use of laboratory test results in patient management by clinicians in Malawi. Afr J Lab Med. 2015; 4(1):1-8

22. Benatar, S. R. Health care reform and the crisis of HIV and AIDS in South Africa. N Engl J Med. 2004; 351: 81-92.

23. Mepham, S. O., Squire, S. B., Chisuwo, L., Kandulu, J., and Bates, I. Utilisation of laboratory services by health workers in a district hospital in Malawi. J Clin Pathol. 2009; 62 (10): 935-938.

24. Fadare, O. J., Ogunleye, O., Iliyasu, G., Adeoti, A., Schellack, N., Engler, D., Massele, A., and Godman, B. Status of antimicrobial stewardship programmes in Nigerian tertiary healthcare facilities: Findings and implications. J Glob Antimicrob Resist. 2019; 17: 132-136

25. Imanpour, S., Nwaiwu, O., McMaughan, D. K. DeSalvo, B., and Bashir, A. Factors associated with antibiotic prescriptions for the viral origin diseases in office-based practices, 2006-2012. JRSM Open. 2017; 8: 1-8 